\title{
Identification of Factors Influencing Anemia among Children Aged 6-59 Months in Ethiopia Using Ethiopia Demographic and Health Survey 2016 Data
}

This article was published in the following Dove Press journal:

Pediatric Health, Medicine and Therapeutics

\author{
Ataklti Gebretsadik \\ Woldegebriel' \\ Gebremedhin Gebreegziabiher \\ Gebrehiwot (iD) $^{2}$ \\ Abraham Aregay Desta (iD' \\ Kiros Fenta Ajemu (iD) ' \\ Asfawosen Aregay Berhe (iD) ' \\ Tewolde Wubayehu \\ Woldearegay' \\ Nega Mamo Bezabih' \\ 'Department of Human Nutrition, Tigray \\ Health Research Institute, Mekelle, \\ Tigray, Ethiopia; ${ }^{2}$ Department of Human \\ Nutrition, School of Public Health, \\ Adigrat University, Adigrat, Tigray, \\ Ethiopia
}

Background: Anemia is the most common nutritional problem and a widespread micronutrient-deficiency disorder on a global scale. In Ethiopia, childhood anemia is highly prevalent and a major public health concern. This study aimed to identify factors associated with anemia among children aged 6-59 months in Ethiopia.

Methods: Data weres extracted from the 2016 Ethiopia Demographic and Health Survey (EDHS). We found records for 8,603 children aged 6-59 months in the data set. After 448 had been excluded due to incomplete records, 8,155 children were included in the final analysis. Pearson's $\chi^{2}$ was used to assess associations between each factor and categorical outcome variables. Multivariate logistic regression analyses were done to determine factors associated with anemia, and significant associations were declared at $p \leq 0.05$ for the final model.

Results: More than half (51.5\%) the children were male and the overall mean age was 31.85 \pm 15.66 months. Mean hemoglobin concentration was $10.37 \pm 17.55 \mathrm{~g} / \mathrm{dL}$. The overall prevalence of anemia was $56.6 \%: 3.7 \%, 30.4 \%$, and $22.5 \%$ severe, moderate, and mild anemia, respectively. Increased child age, decreased maternal age, lowest rung on wealth index, mother living alone, mother engaged in outside work, increased birth order, decreased birth interval, one antenatal care visit, severe stunting, and severe underweight were significantly associated with anemia.

Conclusion: The prevalence of anemia in this study was the highest of all EDHS reports. It had increased since the preceding report (EDHS 2011), and remains the main public health concern in Ethiopia. Comprehensive intervention strategies should be put in place and tailored to different levels of government (national, regional, and district) including household- and individual-level interventions for combating childhood anemia by focusing on the identified risk factors.

Keywords: anemia, associated, children, EDHS 2016, Ethiopia

\section{Background}

Globally, anemia is the most common nutritional concern and widespread public health micro-nutrient-deficiency disorder, and affects more than 2 billion people. According to the World Health Organization (WHO), it is one of the top ten health concerns in the world. ${ }^{1,2}$ It affects both developed and developing countries, with major consequences for human health, as well as social and economic development. ${ }^{3,4}$

Childhood anemia is a condition where a child has insufficient hemoglobin $(<11 \mathrm{~g} / \mathrm{dL})$ to provide adequate oxygen to body tissue. ${ }^{5}$ In children, anemia results
Correspondence: Ataklti Gebretsadik Woldegebriel

Tigray Health Research Institute, Mekelle, Tigray, 1547, Ethiopia

Email atakltigebertsadik@gmail.com
Pediatric Health, Medicine and Therapeutics 2021:12 I6I-175

| 6 |

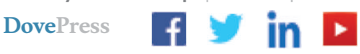


in low oxygenation of brain tissue, which in turn leads to impaired cognitive function, growth, and psychomotor development. This leads to reduced academic achievement and low income-earning potential in their adulthood. ${ }^{6}$ Although anemia can occur at any time and at all stages of the life cycle, ${ }^{7}$ anemia in aged $<5$ years is in terms of its morbidity and mortality. ${ }^{8}$

Globally, $43 \%$ of preschool children are anemic. ${ }^{9}$ A study conducted in sub-Saharan Africa revealed that the prevalence of anemia among children aged 6-59 months was $59 \%$, ranging from $23.7 \%$ in Rwanda to $87.9 \%$ in Burkina Faso. ${ }^{10}$ In Ethiopia, childhood anemia is a big public health concern. The trend of anemia among children aged 6-59 months declined from 54\% in 2005 to $44 \%$ in 2011 , but increased to $56.6 \%$ in the 2016 Ethiopia Demographic and Health Survey (EDHS). ${ }^{11}$

Though several studies have been conducted in various settings in the country, most have lacked consistency, used unrepresentative sample and poor laboratory testing methods (Sahliheillage method) for hemoglobin determination, and did not include associated factors in the data collected. With the high prevalence of childhood anemia in Ethiopia, identifying and addressing associated factors could be an important step in designing successful intervention strategies at the national level. Therefore, this study was designed to assess factors associated with anemia among children aged 6-59 months in Ethiopia to inform health authorities at different levels of government on risk factors to be targeted and measures to be taken to prevent and control childhood anemia.

\section{Methods}

\section{Data Source, Study Setting, Study Design, and Population}

EDHSs are conducted every 5 years. The 2016 EDHS was the fourth and most recent in Ethiopia, following the 2000, 2005, and 2011 EDHSs. The 2016 EDHS was conducted on a nationally representative sample of nine regional states and two city administrations, subdivided into 68 zones, 817 districts, and 16,253 kebeles (lowest local administrative units of the nation). The full data set of EDHS 2016 is available and accessible on the DHS program website: http://dhsprogram.com/data/dataset/ EthiopiaStandard-DHS 2016.cfm. Children 6-59 months of age with hemoglobin-level records were included in this study. A community-based cross-sectional study design was used. The children were selected randomly.

\section{Sample-Size Determination and Sampling Procedure}

Study participants selected using a stratified two-stage cluster design and enumeration areas were the sampling units for the first stage. In this stage, 645 enumeration areas were randomly selected: 202 in urban areas and 443 in rural areas. In the second stage, a fixed number of 28 households per cluster were selected randomly for each enumeration area. The 18,060 households were randomly selected, and 16,650 households were eligible and interviewed. Additional information about the methodology of EDHS 2016 can be accessed in the published report of the main findings of the survey. ${ }^{11}$

Every child in the selected households was included, and data were collected on various health and nutrition variables, in addition to measurement of hemoglobin levels for children aged 6-59 months. As our focus in this study was in these children, we extracted the EDHS 2016 data set. We found data records for 8,603 children in this age-group. After exclusion of 448 due to incomplete records, 8,155 were included in the final analysis (Figure 1).

\section{Dependent Variable}

The outcome variable was anemia status of children aged 6-59 months.

\section{Independent Variables}

Selection of the independent variables was guided by the literature and availability of the variables in the data set. ${ }^{12-16}$ Some of the independent variables for anemia among children 6-59 months follow.

\section{Maternal Characteristics}

Maternal age, educational status, antenatal care follow-up, currently living with husband or not, engaged in paid work or not, deworming during pregnancy, and body-mass index $\left(\mathrm{BMI} ; \mathrm{kg} / \mathrm{m}^{2}\right.$ ) data were gathered.

\section{Household Characteristics}

These comprised a wealth index (poorest, poor, middle, rich, and richest), number of household members, number of under five children aged $<5$ years in the household, sex of household head, and residence.

\section{Child Characteristics}

These comprised child age, birth order, birth interval, birth status (single/multiple), recent diarrhea, stunting, wasting, underweight, and vitamin A supplementation in the preceding 6 months. 


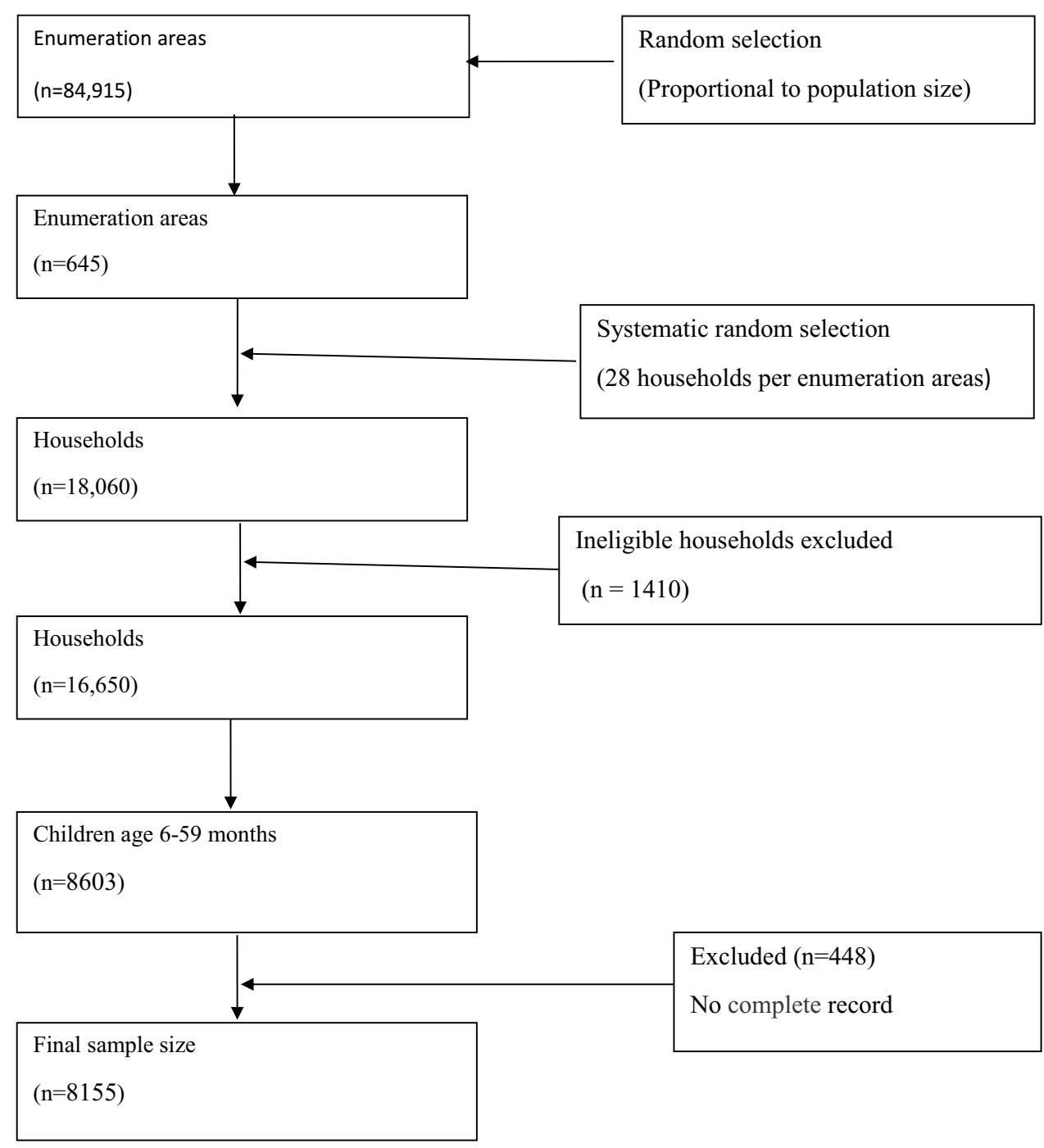

Figure I Flowchart of sample-selection technique $(n=8,155)$.

\section{Hematologic Measurement}

Blood samples were drawn from the finger or heel, and hemoglobin level for each child was measured adjusted to altitude with a HemoCue 201 analyzer. Anemia was defined as hemoglobin $<11 \mathrm{~g} / \mathrm{dL}$, and categorized into mild, moderate, and severe anemia by measures of 10 $<11 \mathrm{~g} / \mathrm{dL}, 7-<10 \mathrm{~g} / \mathrm{dL}$, and $<7 \mathrm{~g} / \mathrm{dL}$, respectively. ${ }^{11}$

\section{Anthropometric Measurements}

The height of children aged $<24$ months was measured during the EDHS in a recumbent position to the nearest $0.1 \mathrm{~cm}$ using a measuring board with an upright wooden base and movable headpieces. Children $\geq 24$ months were measured standing upright. Data collectors used a stadimeter for height measurement, with subjects positioned at the Frankfurt plane and the four points (heel, calf, buttock, and shoulder) touching the vertical stand and without shoes. Weight was measured using a digital scale with children in light clothes and without shoes. The validity of the weighing scale was checked before starting in the morning and between each measurement using a known weight. Height- and weight-measuring devices were placed on a level surface. All anthropometric measurements were done in triplicate and average values used for further analyses. Underweight, stunting, and wasting were calculated using the WHO child-growth standards and defined as WAZ, HAZ, and WHZ $<-2.0 \mathrm{SD}$, respectively. ${ }^{16}$

\section{Wealth Index}

A wealth index in the EDHS survey was calculated based on household-asset data to categorize individuals into five wealth quintiles (poorest, poor, medium, rich, and richest). Variables included in the wealth index were ownership of 
selected household assets (television, bicycle, or car), size of agricultural land, quantity of livestock, and materials used for house construction. ${ }^{17}$

\section{Data Analysis}

After data had been extracted, we checked for completeness and consistency and performed preliminary analyses. Sample weights were applied in all analyses (due to the two-stage cluster sampling design in the EDHS data set) to correct for the unequal probability of selection among the strata. ${ }^{11}$ Data analysis was carried out using Stata 14. Descriptive statistics wwere used for frequencies and percentages for categorical variables and means \pm SD for continuous variables. $\chi^{2}$ and Students $t$-tests were used to assess significant differences in categorical and continuous variables, respectively.

Bivariate logistic regression was fitted to check for presence or absence of association between each independent variable and anemia. Those explanatory variables with $p-<0.05$ on bivariate analysis were included in the final multivariate logistic regression analysis to adjust for confounding and to identify final factors associated with anemia. Backward logistic regression was used for multivariate analysis. The goodness of fit of the final logistic model was tested using Hosmer-Lemeshow test at $p>0.05$. Results for outcome measures are indicated with ORs and $95 \%$ CIs. Significance was declared at $p \leq 0.05$ for the final logistic regression model.

\section{Ethics Considerations}

The study proposal got ethical approval from the Tigray Health Research Institute, and a formal letter of permission was obtained from the DHS Program website to access the data set (http://www.measuredhs.com).

\section{Results}

\section{Sociodemographic and Other} Characteristics of Mothers

Half (49.6\%) the mothers/caregivers of the children were aged 20-29 years, and $64.7 \%$ were Illiterate. A majority (81.9\%) were rural residents, and $71.4 \%$ were not currently in paid work. More than a third (36.7\%) of households were classified within the poorest rank of the wealth index. A third (33.6\%) of mothers had not visited antenatal care (ANC) units, and $37.1 \%$ reported the recommended number of ANC visits (four and above) during their recent pregnancy. A quarter $(24.7 \%)$ of mothers were underweight, and one in ten $(9.3 \%)$ overweight and obese. Half $(50.8 \%)$ the households had four to six family members, $79.1 \%$ were headed by the man (Table 1).

\section{Characteristics of Children}

Data on 8,155 children were included in the analysis. More than half $(51.5 \%)$ were male, and mean age was $31.85 \pm 15.66$ months, with no significant mean age

Table I Sociodemographic and Other Characteristics of Mothers, EDHS $2016(n=8,155)$

\begin{tabular}{|c|c|c|c|}
\hline & & $\mathbf{n}$ & $\%$ \\
\hline \multirow[t]{7}{*}{ Age (years) } & $<20$ & 243 & $3.0 \%$ \\
\hline & $20-24$ & 1,592 & $19.5 \%$ \\
\hline & $25-29$ & 2,456 & $30.1 \%$ \\
\hline & $30-34$ & $\mathrm{I}, 864$ & $22.9 \%$ \\
\hline & $35-39$ & 1,299 & $15.9 \%$ \\
\hline & $40-44$ & 535 & $6.6 \%$ \\
\hline & $\geq 45$ & 166 & $2.0 \%$ \\
\hline \multirow[t]{4}{*}{ Education } & None & 5,277 & $64.7 \%$ \\
\hline & Primary & 2,065 & $25.3 \%$ \\
\hline & Secondary & 525 & $6.4 \%$ \\
\hline & Tertiary & 288 & $3.5 \%$ \\
\hline \multirow[t]{4}{*}{ BMI } & Underweight & 2,016 & $24.7 \%$ \\
\hline & Normal & 5,383 & $66.0 \%$ \\
\hline & Overweight & 578 & $7.1 \%$ \\
\hline & Obese & 171 & $2.1 \%$ \\
\hline \multirow[t]{5}{*}{ ANC follow-up } & Zero & I,803 & $33.6 \%$ \\
\hline & One & 245 & $4.6 \%$ \\
\hline & Two & 395 & $7.4 \%$ \\
\hline & Three & 933 & $17.4 \%$ \\
\hline & Four and above & 1,995 & $37.1 \%$ \\
\hline \multirow[t]{2}{*}{ Engaged in paid work } & Yes & 2,330 & $28.6 \%$ \\
\hline & No & 5,825 & $71.4 \%$ \\
\hline \multirow[t]{2}{*}{ Residence } & Rural & 6,681 & $81.9 \%$ \\
\hline & Urban & $\mathrm{I}, 474$ & $18.1 \%$ \\
\hline \multirow[t]{4}{*}{ Number of household members } & $<4$ & 876 & $10.7 \%$ \\
\hline & $4-6$ & 4,143 & $50.8 \%$ \\
\hline & $7-9$ & 2,626 & $32.2 \%$ \\
\hline & $\geq 10$ & 510 & $6.3 \%$ \\
\hline \multirow[t]{2}{*}{ Sex of household head } & Male & 6,447 & $79.1 \%$ \\
\hline & Female & $\mathrm{I}, 708$ & $20.9 \%$ \\
\hline \multirow[t]{5}{*}{ Wealth index } & Poorest & 2,996 & $36.7 \%$ \\
\hline & Poor & 1,416 & $17.4 \%$ \\
\hline & Middle & I, 175 & $14.4 \%$ \\
\hline & Rich & $\mathrm{I}, 005$ & $12.3 \%$ \\
\hline & Richest & 1,563 & $19.2 \%$ \\
\hline
\end{tabular}

Abbreviations: BMI, body-mass index; ANC, antenatal care. 
difference between the sexes $(p=0.107)$. In sum, $81.9 \%$ were rural residents. More than a third $(36.5 \%)$ were born first or second. The mean birth interval was $38.29 \pm 22.15$, significantly higher $(38.66 \pm 22.06)$ for girls than boys (37.93 $\pm 22.24 ; p=0.001)$. More than a third $(35.5 \%)$ of households had only one child aged $<5$ years, and $45.6 \%$ households had two. The prevalence of stunting, underweight, and wasting was $38 \%, 24 \%$, and $10 \%$, respectively. The prevalence of stunting was significantly higher $(39.4 \%)$ in boys than girls $(36.6 \% ; p=0.014)$, as was the prevalence of wasting $(10.8 \%$ vs $9.1 \%, p=0.026)$. Less than half (47.9\%) participants had had vitamin A supplements in the preceding 6 months, and only $2.4 \%$ had multiple birth status. Around 11.8\% reported recent diarrhea (Table 2).

\section{Prevalence of Anemia Stratified by Sex}

The overall prevalence of anemia was 56.6\%: $3.7 \%$, $30.4 \%$, and $22.5 \%$ severe, moderate, and mild, respectively (Figure 2). Mean hemoglobin concentration was $10.37 \pm 17.55 \mathrm{~g} / \mathrm{dL}$, with no significant difference between the sexes $(p=0.355)$. Anemia was most prevalent in Somali state, followed by Afar and Oromia states, with prevalence of $73.9 \%, 70.4 \%$, and $62.4 \%$, respectively. The lowest prevalence $(41.2 \%)$ was found in Amhara state (Figure $3)$. Anemia prevalence significantly decreased with age ( $p<0.001): 73.5 \%$ for the lowest range (6-11 months) and $40.0 \%$ for the highest (48-59 months). As child age increased, so did hemoglobin concentration $(r=\sim 0.3$, Figure 4). Anemia prevalence also significantly decreased with increased birth interval $(p<0.001)$. Prevalence was $52.6 \%, 63.0 \%$, and $50.0 \%$ among firstborn children, lowest birth interval ( $<24$ months), and highest birth interval ( $\geq 48$ months), respectively. Anemia prevalence significantly increased with increasing birth order of the child $(p<0.001)$, with a prevalence of $52.7 \%$ for first and $59.8 \%$ for the highest (eighth and above). Anemia prevalence significantly increased with increasing number of childrenaged 5 years in the household $(p<0.001)$ with prevalence of $50.6 \%, 58.1 \%$, and $64.9 \%$ in households with one, two, and three or more children aged $<5$ years, respectively.

Children who had had recent diarrhea showed significantly higher $(61.9 \%)$ anemia prevalence than those who had not $(55.9 \% ; p<0.001)$. Children who had been supplemented with vitamin $\mathrm{A}$ in the preceding 6 months had significantly lower $(54.0 \%)$ anemia prevalence than those who had not $(59.1 \% ; p<0.001)$. Anemia prevalence among children also significantly increased with increasing severity of stunting, underweight, and wasting $(p<0.001)$. With regard to nutritional status, the highest prevalence of anemia was among severely wasted children, followed by severely underweight and severely stunted children: $73.2 \%, 71.1 \%$, and $64.9 \%$, respectively.

Significantly higher anemia prevalence was documented among rural children (58.4\%) than urban children $(48.3 \% ; p<0.001)$. Anemia significantly and consistently decreased with increasing maternal age $(p<0.001)$, with the highest $(68.3 \%)$ prevalence among the lowest agegroup ( $<20$ years) and the lowest $(44.0 \%)$ among the highest age-group ( $\geq 45$ years). As the literacy of the mother increased, anemia prevalence among children consistently and significantly decreased $(p<0.001)$, with prevalence of $59.2 \%, 54.8 \%, 47.6 \%$, and $39.6 \%$ among mothers who could not read or write and those with primary, secondary, and tertiary education, respectively. Anemia significantly decreased with increasing wealth index of the household $(p<0.001)$. The highest prevalence $(65.7 \%)$ was documented in the poorest households, and the lowest $(46.6 \%)$ in the richest households. As nutritional status of the mother (indicated by BMI) increased, anemia prevalence among children significantly decreased $(p<0.001)$. However, a slight shift was observed for obese mothers. Prevalence was highest (61.4\%) among children of underweight mothers, followed by normal $(55.8 \%)$ and overweight (48.6\%) mothers, and slightly increased $(51.5 \%)$ among children of obese mothers (Table 3, Figure 5).

\section{Factors Associated with Anemia}

On multivariate logistic regression analysis, increased child age, decreased maternal age, poorest rank of wealth index, mother living alone, mother engaged in outside work, increased birth order, decreased birth interval, one ANC visit, severe stunting, and severe underweight were identified as significant predictors of anemia (Table 4).

The odds of developing anemia in the age-groups 6-11, 12-23, 24-35, and 36-47 months were 6.194 (95\% CI 4.622-8.301), 4.202 (95\% CI 3.267-5.404), 2.155 (95\% CI 1.667-2.787), and 1.499 (95\% CI 1.141-1.968) times, respectively, those of children in the oldest age-group (48-59 months). Those born fourth and fifth, sixth and seventh, and eighth and above had around 37\% (AOR 1.368, 95\% CI 1.086-1.723), 50\% (AOR 1.504, 95\% CI 1.140-1.984), and 80\% (AOR 1.795, 95\% CI 1.2902.495), respectively, higher odds of developing anemia than firstborns. The odds of developing anemia among 
Table 2 Characteristics of Children Stratified by Sex $(n=8,155)$

\begin{tabular}{|c|c|c|c|c|c|c|}
\hline & & All, n (\%) & Male, $n$ (\%) & Female, n (\%) & $\chi^{2}$ & $p$ \\
\hline Sex & & $8,155(100 \%)$ & 4,197 (5I.5\%) & 3,958 (48.5\%) & NA & NA \\
\hline $\mathrm{Ag}$, months (mean $\pm \mathrm{SD}$ ) & & $31.85 \pm 15.66$ & $32.12 \pm 15.59$ & $31.56 \pm 15.73$ & $1.614^{\mathrm{a}}$ & 0.107 \\
\hline Age, months & $\begin{array}{l}6-11 \\
12-23 \\
24-35 \\
36-47 \\
48-59\end{array}$ & $\begin{array}{l}963(\mathrm{I} I .8 \%) \\
\mathrm{I}, 8 \mathrm{I} 3(22.2 \%) \\
\mathrm{I}, 772(2 \mathrm{I} .7 \%) \\
\mathrm{I}, 736(2 \mathrm{I} .3 \%) \\
\mathrm{I}, 87 \mathrm{I}(22.9 \%)\end{array}$ & $\begin{array}{l}486(11.6 \%) \\
897(21.4 \%) \\
931(22.2 \%) \\
901(21.5 \%) \\
982(23.4 \%)\end{array}$ & $\begin{array}{l}477(12.1 \%) \\
916(23.1 \%) \\
841(21.2 \%) \\
835(21.1 \%) \\
889(22.5 \%)\end{array}$ & 4.986 & 0.289 \\
\hline Residence & $\begin{array}{l}\text { Rural } \\
\text { Urban }\end{array}$ & $\begin{array}{l}6,681(81.9 \%) \\
1,474(18.1 \%)\end{array}$ & $\begin{array}{l}3,432(81.8 \%) \\
765(18.2 \%)\end{array}$ & $\begin{array}{l}3,249(82.1 \%) \\
709(17.9 \%)\end{array}$ & 0.136 & 0.712 \\
\hline Birth order & $\begin{array}{l}\text { Ist } \\
\text { 2nd } \\
3 \text { rd } \\
4 \text { th } / 5 \text { th } \\
\text { 6th/7th } \\
\text { 8th and above }\end{array}$ & $\begin{array}{l}\text { I,594 (I9.5\%) } \\
\text { I,386 (I7.0\%) } \\
\text { I,2I I (I4.8\%) } \\
\text { I,920 (23.5\%) } \\
\text { I,287 (I5.8\%) } \\
757(9.3 \%)\end{array}$ & $\begin{array}{l}826(19.7 \%) \\
705(16.8 \%) \\
606(14.4 \%) \\
1,010(24.1 \%) \\
651(15.5 \%) \\
399(9.5 \%)\end{array}$ & $\begin{array}{l}768(19.4 \%) \\
681(17.2 \%) \\
605(15.3 \%) \\
910(23.0 \%) \\
636(16.1 \%) \\
358(9.0 \%)\end{array}$ & 3.129 & 0.680 \\
\hline Recent diarrhea & $\begin{array}{l}\text { Yes } \\
\text { No }\end{array}$ & $\begin{array}{l}961 \text { (II.8\%) } \\
7,182(88.2 \%)\end{array}$ & $\begin{array}{l}519(12.4 \%) \\
3,672(87.6 \%)\end{array}$ & $\begin{array}{l}442 \text { (II.2\%) } \\
3,510(88.8 \%)\end{array}$ & 2.811 & 0.094 \\
\hline Children aged $<5$ years in household & $\begin{array}{l}1 \\
2 \\
3 \text { and more }\end{array}$ & $\begin{array}{l}2,880(35.5 \%) \\
3,696(45.6 \%) \\
1,528(18.9 \%)\end{array}$ & $\begin{array}{l}I, 52 \mathrm{I}(36.4 \%) \\
\mathrm{I}, 868(44.8 \%) \\
784(\mathrm{I} .8 \%)\end{array}$ & $\begin{array}{l}\mathrm{I}, 359(34.6 \%) \\
\mathrm{I}, 828(46.5 \%) \\
744(\mathrm{I} 8.9 \%)\end{array}$ & 3.369 & 0.186 \\
\hline Birth interval, months (mean $\pm S D$ ) & & $38.29 \pm 22.15$ & $37.93 \pm 22.24$ & $38.66 \pm 22.06$ & $3.398^{\mathrm{a}}$ & $0.001^{*}$ \\
\hline Birth interval & $\begin{array}{l}\text { First } \\
<24 \text { months } \\
24-35 \text { months } \\
36-47 \text { months } \\
48-59 \text { months }\end{array}$ & $\begin{array}{l}\text { I,603 (19.7\%) } \\
\text { I,594 (19.5\%) } \\
2,109(25.9 \%) \\
\text { I,304 (16.0\%) } \\
\text { I,545 (I8.9\%) }\end{array}$ & $\begin{array}{l}829(19.8 \%) \\
823(19.6 \%) \\
1,132(27.0 \%) \\
650(15.5 \%) \\
763(18.2 \%)\end{array}$ & $\begin{array}{l}774 \text { (19.6\%) } \\
771 \text { (19.5\%) } \\
977(24.7 \%) \\
654(16.5 \%) \\
782(19.8 \%)\end{array}$ & 8.224 & 0.084 \\
\hline Stunting & $\begin{array}{l}\text { Severe } \\
\text { Moderate } \\
\text { Normal }\end{array}$ & $\begin{array}{l}\text { I,332 (I } 7.3 \%) \\
\text { I,593 (20.7\%) } \\
4,772(62.0 \%)\end{array}$ & $\begin{array}{l}727(18.4 \%) \\
829(21.0 \%) \\
2,393(60.6 \%)\end{array}$ & $\begin{array}{l}607(16.2 \%) \\
765(20.4 \%) \\
2,376(63.4 \%)\end{array}$ & 8.524 & $0.014^{*}$ \\
\hline Underweight & $\begin{array}{l}\text { Severe } \\
\text { Moderate } \\
\text { Normal }\end{array}$ & $\begin{array}{l}576(7.6 \%) \\
1,245(16.4 \%) \\
5,776(76.0 \%)\end{array}$ & $\begin{array}{l}302(7.7 \%) \\
673(17.3 \%) \\
2,922(75.0 \%)\end{array}$ & $\begin{array}{l}274(7.4 \%) \\
572(15.5 \%) \\
2,854(77.1 \%)\end{array}$ & 5.911 & 0.052 \\
\hline Wasting & $\begin{array}{l}\text { Severe } \\
\text { Moderate } \\
\text { Normal }\end{array}$ & $\begin{array}{l}196(2.3 \%) \\
561(7.4 \%) \\
6,842(90.0 \%)\end{array}$ & $\begin{array}{l}106(2.7 \%) \\
314(8.1 \%) \\
3,474(89.2 \%)\end{array}$ & $\begin{array}{l}90(2.4 \%) \\
247(6.7 \%) \\
3,368(90.9 \%)\end{array}$ & 7.303 & $0.026 *$ \\
\hline Vitamin A supplementation in last 6 months & $\begin{array}{l}\text { Yes } \\
\text { No } \\
\text { Do not know }\end{array}$ & $\begin{array}{l}3,686(47.9 \%) \\
3,879(50.5 \%) \\
124(1.6 \%)\end{array}$ & $\begin{array}{l}\mathrm{I}, 894(47.9 \%) \\
\mathrm{I}, 995(50.5 \%) \\
65(\mathrm{I} .6 \%)\end{array}$ & $\begin{array}{l}\mathrm{I}, 792(48.0 \%) \\
\mathrm{I}, 884(50.4 \%) \\
59(\mathrm{I} .6 \%)\end{array}$ & 0.052 & 0.975 \\
\hline Birth status & $\begin{array}{l}\text { Single } \\
\text { Multiple }\end{array}$ & $\begin{array}{l}7,503(97.6 \%) \\
186(2.4 \%)\end{array}$ & $\begin{array}{l}3,857(97.5 \%) \\
97(2.5 \%)\end{array}$ & $\begin{array}{l}3,646(97.6 \%) \\
89(2.4 \%)\end{array}$ & 0.04 & 0.841 \\
\hline
\end{tabular}

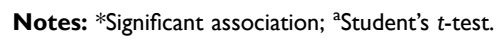

Abbreviation: NA, not applicable. 
Anemia among children

$3.70 \%$

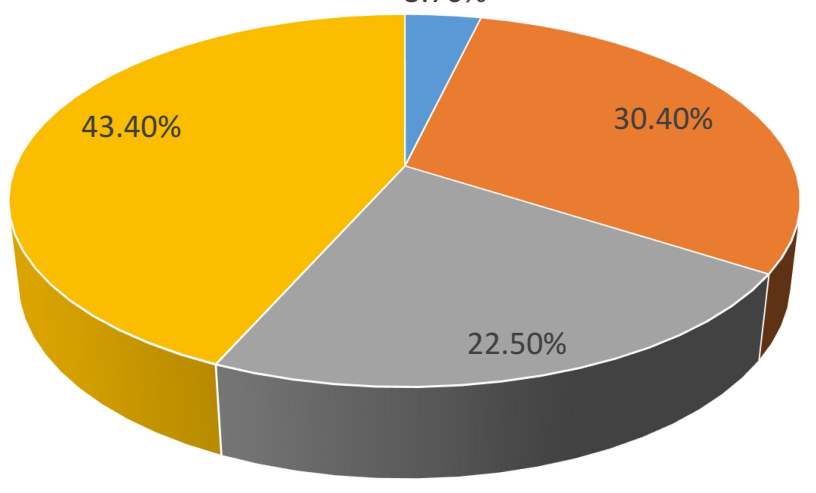

- Severe - Moderate - Mild - Normal

Figure 2 Severity of anemia $(n=8,155)$.

children with birth intervals of $<18,18-23$, and $24-35$ months were 1.715 (95\% CI 1.259-2.336), 1.593 (95\% CI 1.223-2.075), and 1.425 (95\% CI 1.174-1.730) times, respectively, those of children with the greatest birth interval ( $\geq 48$ months). Severely stunted and severely underweight children were 1.467 (95\% CI 1.142-1.885) and1.458 (95\% CI 1.044-2.035) times, respectively, as likely to be anemic as normal children.

Children from mothers aged $<20,20-29$, and 30-39 years were 3.409 (95\% CI 1.143-10.726), 1.643 (95\% CI 1.211-2.229), and 1.293 (95\% CI 1.006-1.662) times, respectively, as likely to be anemic as children whose mothers were in the highest age-group (40-49 years). The odds of developing anemia among children whose mothers were not living with their husband were 1.308 (95\% CI 1.024-1.670) times those of children whose mothers were living with their husband. Children from mothers engaged in paid work were 1.251 (95\% CI $1.073-1.462$ ) times as likely to be anemic as children of housewives. Children whose mothers had had only one ANC visit during pregnancy were 1.501 (95\% CI $1.017-$ 1.216) times as likely to develop anemia as children whose mothers had had the recommended number of ANC visits. Children from the poorest households were around 1.552

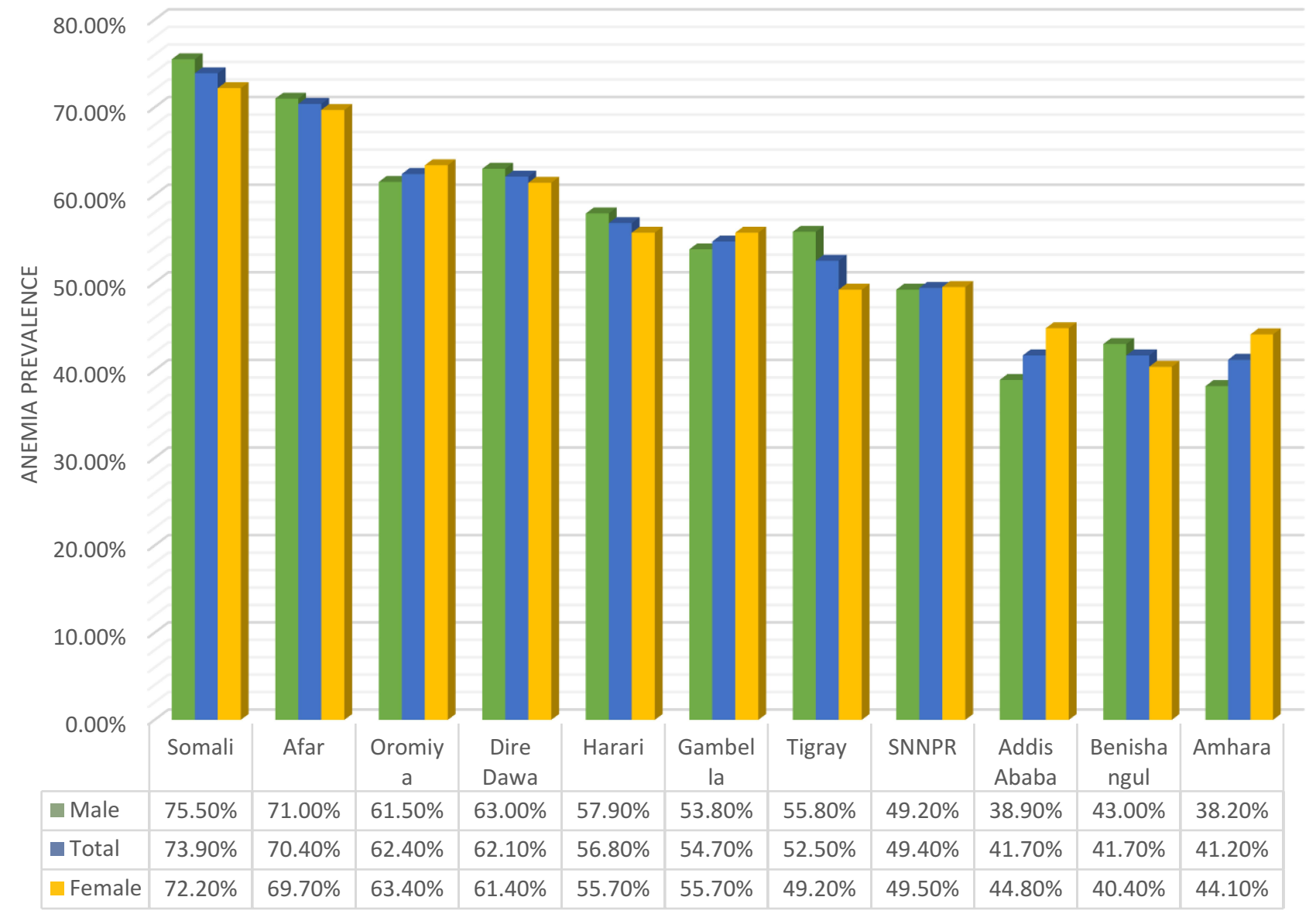

Figure 3 Anemia distribution regional states stratified by sex, $(n=8,155)$. 


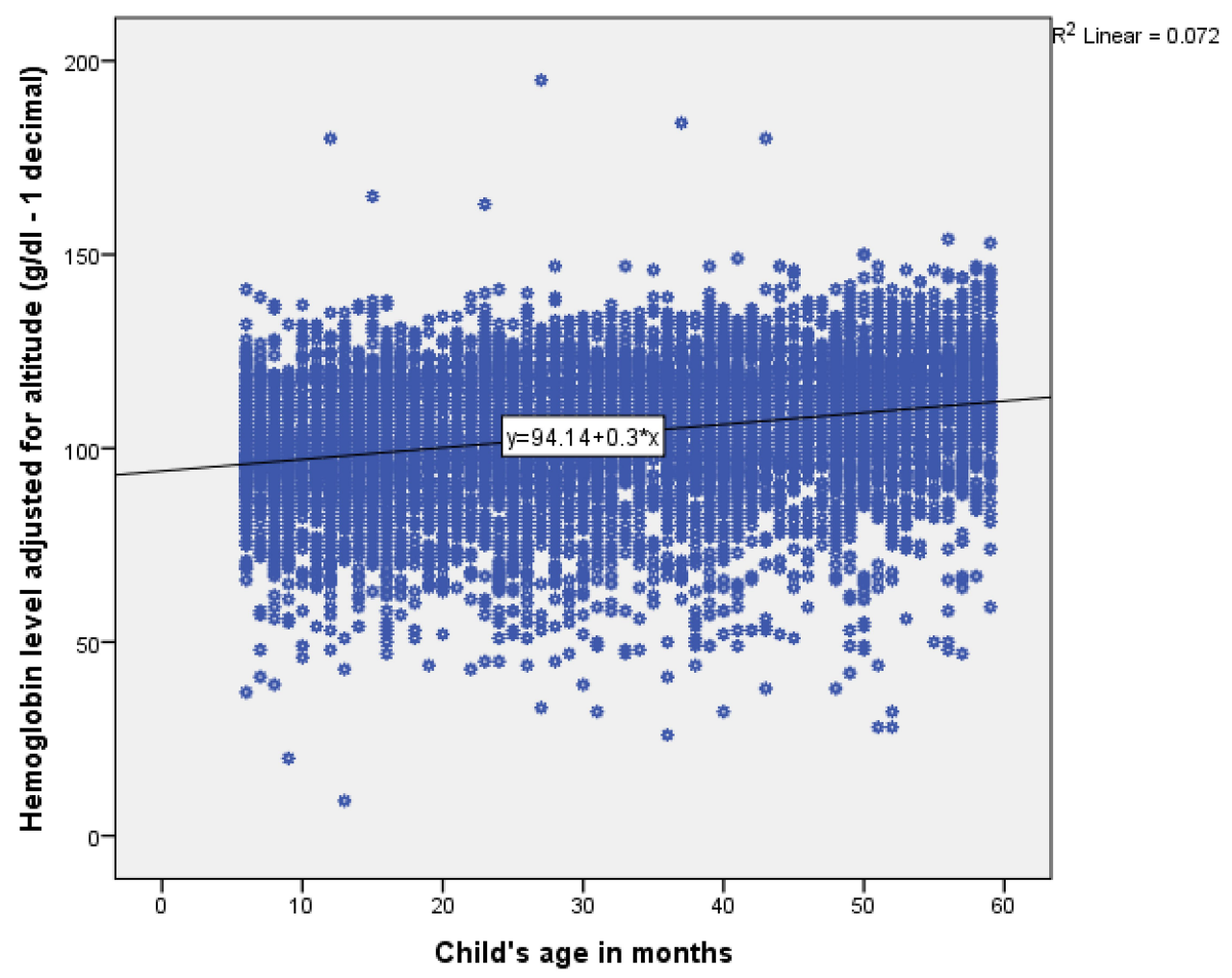

Figure 4 Trend of hemoglobin concentration $(n=8,155)$.

(95\% CI 1.235-1.950) as likely to be anemic as children from the richest households (Table 4).

\section{Discussion}

This study assessed factors associated with anemia among children aged 6-59 months in Ethiopia. Anemia in children is a major public health problem and among the most common causes of child death in Ethiopia. ${ }^{18}$ The overall prevalence of anemia in the present study was $56.6 \%: 3.7 \%, 30.4 \%$, and $22.5 \%$ severe, moderate, and mild anemia, respectively. Even though a high rate of breastfeeding has been reported in Ethiopia, breast milk is low in iron content. Cereal (plant)-based food is commonly consumed in Ethiopia, and is low in iron content and has poor bioavailability, due to phytate (which can mask iron observation) and other inhibitors. ${ }^{11}$ The magnitude of anemia found in this study was severe according to WHO classification. ${ }^{19}$ The present finding is in agreement with studies done in developing countries. The present study finding was similar to a study from Uganda (58.8\%) and ${ }^{20}$ Bangladesh national representative data $(51.9 \%)^{21}$ and higher than studies done in Gondar, Ethiopia $(28.6 \%)^{22}$ and Honduras $(39 \%)^{23}$ on children. However, the result of the present study is lower than studies conducted in Togo $(84.6 \%)^{24}$ and Ghana (78.4\%). ${ }^{26}$ The difference in prevalence might be due to variations in sample size, parent sociodemographic status, geographic location, sampling techniques, socioeconomic status, type of diet consumed by children, and other associated factors.

With an increase in child age, the risk of anemia decreased in all age categories. A similar effect ohas been observed in previous studies. ${ }^{21-23,25-27} \mathrm{~A}$ possible reason for the elevated level of anemia in younger children might be low balanced dietary intake that is in sufficient to satisfy the relatively higher iron requirement due to rapid growth. ${ }^{28}$ An additional reason could be that younger children in Ethiopia depend mostly on breast milk, which is poor in iron content, and complementary food is entirely plant-based which is poor in bioavailability and rich in absorption inhibitors like phytate. Another possible reason might be poor infant- and young child-feeding practices. ${ }^{29}$ Iron stores are generally depleted by the age of 6 months, while blood volume doubles from 4 to 12 months after birth. Dietary sources of iron are crucial to keep up with the rapid rate of red blood-cell synthesis, and anemia may 
Table 3 Anemia Status of Children Stratified by Sex $(n=8,155)$

\begin{tabular}{|c|c|c|c|c|c|c|}
\hline & & \multicolumn{3}{|c|}{ Anemia } & \multirow[t]{2}{*}{$\chi^{2} / t$} & \multirow[t]{2}{*}{$\mathbf{p}$} \\
\hline & & All, $n$ (\%) & Male, n (\%) & Female, $n$ (\%) & & \\
\hline Sex & & $4,617(56.6 \%)$ & 2,391 (57.0\%) & $2,226(56.2 \%)$ & 0.440 & 0.507 \\
\hline Hemoglobin, g/dL (mean \pm SD) & & $10.37 \pm 17.55$ & $10.35 \pm 17.69$ & $10.39 \pm 17.39$ & $0.925^{\mathrm{a}}$ & 0.355 \\
\hline Anemia & $\begin{array}{l}\text { Severe } \\
\text { Moderate } \\
\text { Mild }\end{array}$ & $\begin{array}{l}303 \text { (3.7\%) } \\
2,483(30.4 \%) \\
I, 831 \text { (22.5\%) }\end{array}$ & $\begin{array}{l}157(3.7 \%) \\
1,313(31.3 \%) \\
921(21.9 \%)\end{array}$ & $\begin{array}{l}\text { I } 46 \text { (3.7\%) } \\
\text { I, I } 70(29.6 \%) \\
910(23.0 \%)\end{array}$ & 3.415 & 0.332 \\
\hline Age (months) & $\begin{array}{l}6-11 \\
12-23 \\
24-35 \\
36-47 \\
48-59\end{array}$ & $\begin{array}{l}708(73.5 \%) \\
\text { I,250 (68.9\%) } \\
\text { I,040 (58.7\%) } \\
870(50.1 \%) \\
749(40.0 \%)\end{array}$ & $\begin{array}{l}356(73.3 \%) \\
627(69.9 \%) \\
540(58.0 \%) \\
46 \mid(51.2 \%) \\
407(41.4 \%)\end{array}$ & $\begin{array}{l}352(73.8 \%) \\
623(68.0 \%) \\
500(59.5 \%) \\
409(49.0 \%) \\
342(38.5 \%)\end{array}$ & 466.730 & $<0.001 *$ \\
\hline Residence & $\begin{array}{l}\text { Rural } \\
\text { Urban }\end{array}$ & $\begin{array}{l}3,905(58.4 \%) \\
7 \mid 2(48.3 \%)\end{array}$ & $\begin{array}{l}2,009(58.5 \%) \\
382(49.9 \%)\end{array}$ & $\begin{array}{l}1,896(58.4 \%) \\
330(46.5 \%)\end{array}$ & 50.604 & $<0.001 *$ \\
\hline Birth order & $\begin{array}{l}\text { First } \\
\text { Second } \\
\text { Third } \\
\text { 4th and 5th } \\
\text { 6th and 7th } \\
\text { 8th and above }\end{array}$ & $\begin{array}{l}840(52.7 \%) \\
746(53.8 \%) \\
705(58.2 \%) \\
1,106(57.6 \%) \\
767(59.6 \%) \\
453(59.8 \%)\end{array}$ & $\begin{array}{l}460(55.7 \%) \\
37 \mid(52.6 \%) \\
358(59.1 \%) \\
580(57.4 \%) \\
391(60.1 \%) \\
231(57.9 \%)\end{array}$ & $\begin{array}{l}380(49.5 \%) \\
375(55.1 \%) \\
347(57.4 \%) \\
526(57.8 \%) \\
376(59.1 \%) \\
222(62.0 \%)\end{array}$ & 24.248 & $<0.001 *$ \\
\hline Recent diarrhea & $\begin{array}{l}\text { Yes } \\
\text { No }\end{array}$ & $\begin{array}{l}595(61.9 \%) \\
4,015(55.9 \%)\end{array}$ & $\begin{array}{l}325(62.6 \%) \\
2,063(56.2 \%)\end{array}$ & $\begin{array}{l}270(61.1 \%) \\
1,952(55.6 \%)\end{array}$ & 12.468 & $<0.001 *$ \\
\hline Number ofchildren aged $<5$ years & $\begin{array}{l}1 \\
2 \\
3 \text { and more }\end{array}$ & $\begin{array}{l}I, 456(50.6 \%) \\
2, \mid 46(58.1 \%) \\
992(64.9 \%)\end{array}$ & $\begin{array}{l}787(5 \mathrm{I} .7 \%) \\
\mathrm{I}, 085(58.1 \%) \\
507(64.7 \%)\end{array}$ & $\begin{array}{l}669(49.2 \%) \\
I, 06 \mathrm{I}(58.0 \%) \\
485(65.2 \%)\end{array}$ & 89.146 & $<0.001 *$ \\
\hline Birth interval & $\begin{array}{l}\text { First } \\
<24 \text { months } \\
24-35 \text { months } \\
36-47 \text { months } \\
\geq 48 \text { months }\end{array}$ & $\begin{array}{l}843(52.6 \%) \\
\text { I,005 (63.0\%) } \\
\text { I,275 (60.5\%) } \\
72 \text { I (55.3\%) } \\
773(50.0 \%)\end{array}$ & $\begin{array}{l}462(55.7 \%) \\
523(63.5 \%) \\
672(59.4 \%) \\
344(52.9 \%) \\
390(51.1 \%)\end{array}$ & $\begin{array}{l}381(49.2 \%) \\
482(62.5 \%) \\
603(61.7 \%) \\
377(57.6 \%) \\
383(49.0 \%)\end{array}$ & 78.291 & $<0.001 *$ \\
\hline Stunting & $\begin{array}{l}\text { Severe } \\
\text { Moderate } \\
\text { Normal }\end{array}$ & $\begin{array}{l}864(64.9 \%) \\
902(56.6 \%) \\
2,567(53.8 \%)\end{array}$ & $\begin{array}{l}476(65.5 \%) \\
48 \mathrm{I}(58.0 \%) \\
I, 285(53.7 \%)\end{array}$ & $\begin{array}{l}389(64.1 \%) \\
422(55.1 \%) \\
I, 281(53.9 \%)\end{array}$ & 52.968 & $<0.001 *$ \\
\hline Underweight & $\begin{array}{l}\text { Severe } \\
\text { Moderate } \\
\text { Normal }\end{array}$ & $\begin{array}{l}410(71.1 \%) \\
752(60.4 \%) \\
3,107(53.8 \%)\end{array}$ & $\begin{array}{l}217(71.1 \%) \\
4 I I(6 I .1 \%) \\
I, 577(54.0 \%)\end{array}$ & $\begin{array}{l}\text { I } 93 \text { (70.5\%) } \\
34 \text { I (59.6\%) } \\
\text { I,532 (53.7\%) }\end{array}$ & 83.292 & $<0.001 *$ \\
\hline Wasting & $\begin{array}{l}\text { Severe } \\
\text { Moderate } \\
\text { Normal }\end{array}$ & $\begin{array}{l}\mid 43(73.2 \%) \\
36 \mid(64.4 \%) \\
3,777(55.2 \%)\end{array}$ & $\begin{array}{l}83(78.2 \%) \\
204(64.9 \%) \\
1,925(55.4 \%)\end{array}$ & $\begin{array}{l}60(67.4 \%) \\
157(63.8 \%) \\
I, 852(55.0 \%)\end{array}$ & 48.612 & $<0.001 *$ \\
\hline Vitamin A supplementation in past 6 months & $\begin{array}{l}\text { Yes } \\
\text { No }\end{array}$ & $\begin{array}{l}2,095(54.0 \%) \\
2,450(59.1 \%)\end{array}$ & $\begin{array}{l}\text { I,084 (54.3\%) } \\
\text { I,267 (59.3\%) }\end{array}$ & $\begin{array}{l}\text { I,0II (53.6\%) } \\
\text { I, I } 83 \text { (58.8\%) }\end{array}$ & 21.448 & $<0.001 *$ \\
\hline Birth status & $\begin{array}{l}\text { Single } \\
\text { Multiple }\end{array}$ & $\begin{array}{l}4,504(56.5 \%) \\
113(60.1 \%)\end{array}$ & $\begin{array}{l}2,328(56.8 \%) \\
63(64.9 \%)\end{array}$ & $\begin{array}{l}2,176(56.3 \%) \\
50(54.9 \%)\end{array}$ & 0.955 & 0.329 \\
\hline
\end{tabular}

(Continued) 
Table 3 (Continued).

\begin{tabular}{|c|c|c|c|c|c|c|}
\hline & & \multicolumn{3}{|c|}{ Anemia } & \multirow[t]{2}{*}{$\chi^{2} / t$} & \multirow[t]{2}{*}{$\mathbf{p}$} \\
\hline & & All, n (\%) & Male, n (\%) & Female, n (\%) & & \\
\hline Maternal age (years) & $\begin{array}{l}<20 \\
20-24 \\
25-29 \\
30-34 \\
35-39 \\
40-44 \\
\geq 45\end{array}$ & $\begin{array}{l}166(68.3 \%) \\
952(59.8 \%) \\
1,416(57.7 \%) \\
1,051(56.4 \%) \\
697(53.7 \%) \\
262(49.0 \%) \\
73(44.0 \%)\end{array}$ & $\begin{array}{l}83(69.2 \%) \\
507(61.0 \%) \\
729(57.8 \%) \\
547(57.5 \%) \\
354(52.8 \%) \\
134(49.6 \%) \\
37(40.2 \%)\end{array}$ & $\begin{array}{l}83(67.5 \%) \\
445(58.5 \%) \\
687(57.5 \%) \\
504(55.3 \%) \\
343(54.6 \%) \\
128(48.3 \%) \\
36(48.6 \%)\end{array}$ & 49.378 & $<0.001 *$ \\
\hline Maternal education & $\begin{array}{l}\text { No education } \\
\text { Primary } \\
\text { Secondary } \\
\text { Tertiary }\end{array}$ & $\begin{array}{l}3, I 22(59.2 \%) \\
I, I 3 \mid(54.8 \%) \\
250(47.6 \%) \\
I I 4(39.6 \%)\end{array}$ & $\begin{array}{l}\mathrm{I}, 6 \mathrm{I} 7(59.5 \%) \\
587(55.2 \%) \\
124(45.8 \%) \\
63(42.9 \%)\end{array}$ & $\begin{array}{l}\text { I,505 (58.8\%) } \\
544(54.3 \%) \\
126(49.6 \%) \\
51(36.2 \%)\end{array}$ & 68.113 & $<0.001 *$ \\
\hline Sex of household head & $\begin{array}{l}\text { Male } \\
\text { Female }\end{array}$ & $\begin{array}{l}3,6 \mathrm{I} 6(56.1 \%) \\
\mathrm{I}, 00 \mathrm{I}(58.6 \%)\end{array}$ & $\begin{array}{l}\mathrm{I}, 85 \mathrm{I}(55.9 \%) \\
540(60.8 \%)\end{array}$ & $\begin{array}{l}\mathrm{I}, 765(56.2 \%) \\
46 \mathrm{I}(56.2 \%)\end{array}$ & 3.487 & 0.062 \\
\hline Wealth index & $\begin{array}{l}\text { Poorest } \\
\text { Poor } \\
\text { Middle } \\
\text { Rich } \\
\text { Richest }\end{array}$ & $\begin{array}{l}1,968(65.7 \%) \\
802(56.6 \%) \\
608(51.7 \%) \\
511(50.8 \%) \\
728(46.6 \%)\end{array}$ & $\begin{array}{l}\text { I,034 (66.8\%) } \\
4 \mathrm{II}(56.4 \%) \\
330(53.7 \%) \\
236(47.2 \%) \\
380(47.1 \%)\end{array}$ & $\begin{array}{l}934(64.5 \%) \\
391(56.9 \%) \\
278(49.6 \%) \\
275(54.5 \%) \\
348(46.0 \%)\end{array}$ & 189.483 & $<0.00 I^{*}$ \\
\hline $\mathrm{BMI}$ of the mother & $\begin{array}{l}\text { Underweight } \\
\text { Normal } \\
\text { Overweight } \\
\text { Obese }\end{array}$ & $\begin{array}{l}\text { I,238 (6I. } .4 \%) \\
3,004(55.8 \%) \\
28 \mathrm{I}(48.6 \%) \\
88(51.5 \%)\end{array}$ & $\begin{array}{l}620(61.5 \%) \\
1,562(56.3 \%) \\
151(48.1 \%) \\
53(54.1 \%)\end{array}$ & $\begin{array}{l}618(61.3 \%) \\
1,442(55.2 \%) \\
130(49.2 \%) \\
35(47.9 \%)\end{array}$ & 37.197 & $<0.001 *$ \\
\hline
\end{tabular}

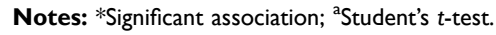

Abbreviation: BMI, body-mass index.

result if dietary sources are inadequate. ${ }^{30,31}$ In addition, frequent childhood infection, due to high susceptibility, can lead to iron malabsorption, which leads to anemia.

Children born of younger mothers were at high risk of childhood anemia, which is consistent with previous study findings. ${ }^{10,32}$ This might be due to lack of knowledge on feeding diversified food to children according to recommended standards. Mothers themselves may have high iron requirements, which could lead to competition with their children for the limited iron intake. Severely stunted and underweight children were more likely to be anemic than their normal counter parts. This finding is consistent with studies conducted elsewhere. ${ }^{21,27,33,34}$ This could be due to anemia or undernutrition, which often have synergism associations with socioeconomic status, sanitation, infections, parasitic diseases, and diet. ${ }^{35}$

Children from the poorest households were 1.6 times as likely to develop anemia as those from the richest ones. This is in line with studies from Bangladesh and Ethiopia. Children from poor families and food-insecure households are at higher risk of developing anemia than their counterparts. ${ }^{21,34,36}$ Children from richest and middleclass households have lower average hemoglobin concentration than those from the poorest households. ${ }^{37}$ The reason could be that the poorest households cannot afford iron-rich animal-based foods and may have poor personal hygiene and environmental sanitation, which leads to infection and micronutrient malabsorption.

Increased birth order was significantly associated with increased childhood anemia, which is in line with previous studies conducted elsewhere. ${ }^{38,40,41}$ This might be due to the distribution of scarce resources within the family and related to maternal exhaustion of micronutrients. Mild maternal iron deficiency and anemia have few significant repercussions on the iron status of the newborn, but severe anemia does have a strong influence.

Birth interval was negatively associated with childhood anemia. The greater the birth interval, the lower the risk of developing anemia among children. This was in line with study findings in other African countries. The effect of the 


\section{TREND OF ANEMIA AMONG CHILDREN}

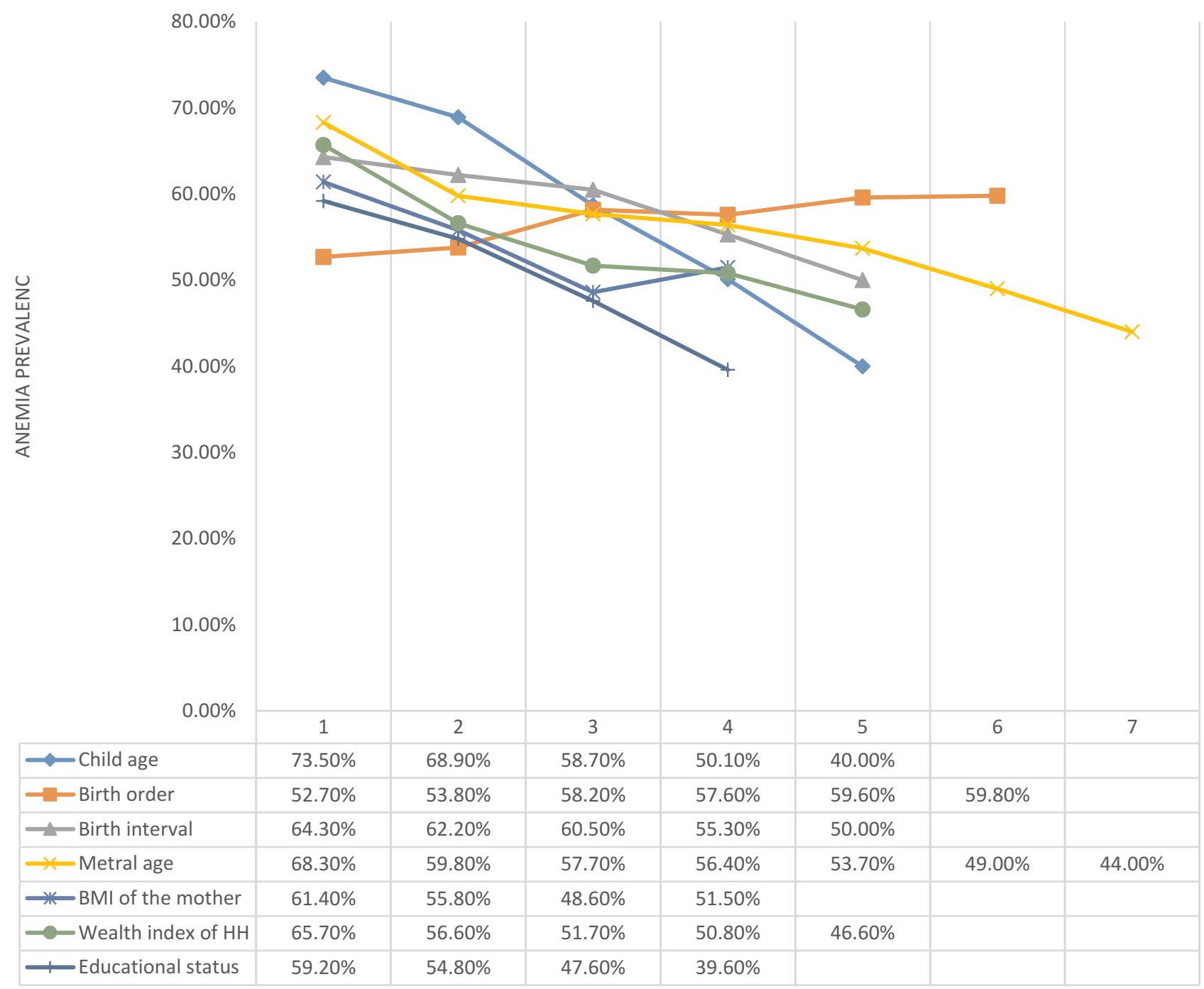

Figure 5 Trends of anemia with respect to child, maternal, and household factors $(n=8,155)$.

birth-interval variable on the index child's hemoglobin level was positive. With every month's increase of from the preceding birth, there is a gain of $0.15 \mathrm{~g} / \mathrm{dL}$ hemoglobin. ${ }^{42,44}$ This might be due to short birth interval causing distribution problems among siblings and parents not being able to take better care of their children, compromising the breastfeeding duration of the previous child. ${ }^{45}$ The mother herself may be biologically exhausted from frequent births, and this could also negatively affect the nutritional status and hemoglobin level of the newborn as a result of the intergenerational link. ${ }^{46}$

Children born of mothers who had had only one ANC visit were 1.5 times as likely to be anemic as children from mothers with the recommended number of ANC visits (four and above). A study conducted in Gondar (Ethiopia) found that home delivery was significantly associated with childhood anemia, ${ }^{22}$ while one from Addis Ababa, indicated that having no ANC visits was significantly associated with maternal anemia. This could be due to the benefit of the recommended number of ANC visits for early diagnosis and treatment of maternal anemia, maternal folate and iron supplementation, provision of deworming medication, malaria prevention, diagnosis, and management, and provision of nutrition counseling, all of which could have a significant impact on childhood anemia. Therefore, mothers should attend the recommended number of ANC visits during the entire period of pregnancy to minimize the risk of childhood anemia. 
Table 4 Factors Associated with Anemia on Bivariate and Multivariate Logistic Regression ( $n=8,155)$

\begin{tabular}{|c|c|c|c|c|c|c|c|}
\hline & & \multicolumn{2}{|c|}{ Anemia } & \multirow[t]{2}{*}{ COR $(95 \% \mathrm{Cl})$} & \multirow[t]{2}{*}{$p$} & \multirow[t]{2}{*}{ AOR $(95 \% \mathrm{Cl})$} & \multirow[t]{2}{*}{$p$} \\
\hline & & Yes, n (\%) & No, n (\%) & & & & \\
\hline \multirow[t]{5}{*}{ Age of child, months } & $6-11$ & $708(73.5)$ & $255(26.5)$ & $4.717(3.923-5.67 I)$ & $<0.00 I^{*}$ & $6.194(4.622-8.301)$ & $<0.001 *$ \\
\hline & $12-23$ & $\mathrm{I}, 250(68.9)$ & $563(31.1)$ & $3.328(2.890-3.832)$ & $<0.00 I^{*}$ & $4.202(3.267-5.404)$ & $<0.001 *$ \\
\hline & $24-35$ & $\mathrm{I}, 040$ & $732(41.3)$ & $2.139(1.866-2.453)$ & $<0.001 *$ & $2.155(1.667-2.787)$ & $<0.001 *$ \\
\hline & $36-47$ & $870(50.1)$ & $866(49.9)$ & $1.500(1.310-1.719)$ & $<0.00 I^{*}$ & $1.499(1.141-1.968)$ & $0.004 *$ \\
\hline & $48-59$ & $749(40.0)$ & $11,22(60.0)$ & I & & I & \\
\hline \multirow[t]{2}{*}{ Sex } & Male & $2,391(57.0)$ & I,806 (43.0) & $1.037(0.947-1.136)$ & 0.435 & & \\
\hline & Female & $2,226(56.2)$ & I,732 (43.8) & 1 & & I & \\
\hline \multirow{4}{*}{ Maternal age, years } & $<20$ & $166(68.3)$ & $70(31.7)$ & $2.618(1.877-3.652)$ & $<0.00 I^{*}$ & $3.409(1.143-10.726)$ & $0.038 *$ \\
\hline & $20-29$ & $2,368(58.5)$ & I,680 (41.5) & $1.537(1.30 \mathrm{I}-1.816)$ & $<0.001 *$ & $1.643(1.211-2.229)$ & $0.001 *$ \\
\hline & $30-39$ & I,748 (55.3) & I,4l5 (44.7) & $1.337(1.128-1.585)$ & $0.00 I^{*}$ & $1.293(1.006-1.662)$ & $0.044^{*}$ \\
\hline & $40-49$ & $335(47.8)$ & $366(52.2)$ & 1 & & I & \\
\hline \multirow{2}{*}{ Residence } & Urban & $712(48.3)$ & $762(51.7)$ & $\mathrm{I}$ & & I & \\
\hline & Rural & $3,905(58.4)$ & $2,776(46.1)$ & $1.339(1.188-1.510)$ & $<0.00 I^{*}$ & $1.432(0.078-26.408)$ & 0.809 \\
\hline \multirow[t]{4}{*}{ Maternal education } & Illiterate & $3,122(59.2)$ & $2,155(40.8)$ & $1.832(1.413-2.375)$ & $<0.001 *$ & $1.440(0.077-26.789)$ & 0.807 \\
\hline & Primary & $\mathrm{I},|3|$ & $934(45.2)$ & $1.506(1.151-1.970)$ & $0.003^{*}$ & $1.164(0.063-21.635)$ & 0.919 \\
\hline & Secondary & $250(47.6)$ & $275(52.4)$ & 1.191 (0.874-1.624) & 0.269 & $1.349(0.068-26.680)$ & 0.844 \\
\hline & Higher & II4 (39.6) & $174(60.4)$ & I & & I & \\
\hline \multirow[t]{4}{*}{ Number of $\mathrm{HH}$ members } & $<4$ & $494(56.4)$ & $382(43.6)$ & 1 & & & \\
\hline & $4-6$ & $2,262(54.6)$ & I,88I (45.4) & $0.871(0.745-1.017)$ & 0.080 & & \\
\hline & $7-9$ & I,555 (59.2) & I,07I (40.8) & $\mathrm{I} .037(0.88 \mathrm{I}-\mathrm{I} .22 \mathrm{I})$ & 0.662 & & \\
\hline & $\geq 10$ & $306(60.0)$ & $204(40.0)$ & I.I24 (0.889-I.42I) & 0.330 & & \\
\hline \multirow[t]{2}{*}{ Sex of $\mathrm{HH}$ head } & Male & $3,616(56.1)$ & $2,831(43.9)$ & I & & I & \\
\hline & Female & $\mathrm{I}, 00 \mathrm{I}(58.6)$ & $707(4 \mid .4)$ & $1.202(1.072-1.348)$ & $0.002^{*}$ & I.I $28(0.863-1.473)$ & 0.378 \\
\hline \multirow[t]{5}{*}{ Wealth index } & Poorest & $1,968(65.7)$ & $\mathrm{I}, 028(34.3)$ & $2.182(1.911-2.491)$ & $<0.00 I^{*}$ & $1.552(1.235-1.950)$ & $<0.001 *$ \\
\hline & Poor & $802(56.6)$ & $614(43.4)$ & $1.317(1.133-1.530)$ & $<0.001 *$ & $1.00 \mid(0.784-1.278)$ & 0.993 \\
\hline & Middle & $608(51.7)$ & $567(48.3)$ & $1.050(0.898-1.228)$ & 0.539 & $0.802(0.628-1.025)$ & 0.079 \\
\hline & Rich & $511(50.8)$ & $494(49.2)$ & $1.022(0.868-1.204)$ & 0.796 & $0.831(0.646-1.070)$ & 0.151 \\
\hline & Richest & $728(46.6)$ & $835(53.4)$ & 1 & & I & \\
\hline \multirow[t]{2}{*}{ Currently living with husband } & Yes & $3,802(56.2)$ & $2,960(43.8)$ & I & & I & \\
\hline & No & $581(63.0)$ & $341(37.0)$ & $1.454(1.248-1.693)$ & $<0.001 *$ & $1.308(1.024-1.670)$ & $0.032 *$ \\
\hline \multirow[t]{2}{*}{ Mother currently working } & Yes & $\mathrm{I}, \mathrm{I} 72(50.3)$ & $\mathrm{I}, \mathrm{I} 58(49.7)$ & $0.702(0.632-0.77 I)$ & $<0.00 I^{*}$ & 1.251 (I.073-I.462) & $0.006 *$ \\
\hline & No & $3,445(59.1)$ & $2,380(40.9)$ & I & & 1 & \\
\hline \multirow[t]{6}{*}{ Birth order of child } & Ist & $840(52.7)$ & $754(47.3)$ & I & & I & \\
\hline & 2nd & $746(53.8)$ & $640(46.2)$ & $1.010(0.869-1.175)$ & 0.893 & & \\
\hline & $3 r d$ & $705(58.2)$ & $506(41.8)$ & I.I58 (0.990-1.355) & 0.066 & $1.258(0.994-1.592)$ & 0.057 \\
\hline & 4th/5th & $\mathrm{I}, 106(57.6)$ & $814(42.4)$ & I.I 48 (0.999-I.32I) & 0.052 & $1.368(1.086-1.723)$ & $0.008^{*}$ \\
\hline & 6th/7th & $767(59.6)$ & $520(40.4)$ & $1.263(1.08 \mathrm{I}-1.475)$ & $0.003^{*}$ & $1.504(1.140-1.984)$ & $0.004 *$ \\
\hline & 8th and above & $453(59.8)$ & $304(40.2)$ & $1.288(1.072-1.548)$ & $0.007^{*}$ & $1.795(1.290-2.495)$ & $0.00 I^{*}$ \\
\hline \multirow[t]{2}{*}{ Birth status } & Single & $4,504(56.5)$ & $3,463(43.5)$ & I & & & \\
\hline & Multiple & $113(60.1)$ & 75 (39.9) & 1.031 (0.765-I.388) & 0.842 & & \\
\hline \multirow[t]{5}{*}{ Birth interval, months } & $<18$ & $427(64.3)$ & $237(35.7)$ & $1.958(1.608-2.385)$ & $<0.001 *$ & 1.715 (1.259-2.336) & $0.001 *$ \\
\hline & $18-23$ & $578(62.2)$ & $352(37.8)$ & $1.810(1.521-2.154)$ & $<0.001 *$ & $1.593(1.223-2.075)$ & $0.001 *$ \\
\hline & $24-35$ & $\mathrm{I}, 275(60.5)$ & $834(39.5)$ & $1.582(1.380-1.814)$ & $<0.001 *$ & 1.425 (I.174-1.730) & $<0.001 *$ \\
\hline & $36-47$ & $721(55.3)$ & $583(44.7)$ & $1.266(1.088-1.475)$ & $0.002^{*}$ & $1.115(0.904-1.374)$ & 0.308 \\
\hline & $\geq 48$ & $773(50.0)$ & $772(50.0)$ & 1 & & 1 & \\
\hline
\end{tabular}

(Continued) 
Table 4 (Continued).

\begin{tabular}{|c|c|c|c|c|c|c|c|}
\hline & & \multicolumn{2}{|c|}{ Anemia } & \multirow[t]{2}{*}{ COR $(95 \% \mathrm{CI})$} & \multirow[t]{2}{*}{$p$} & \multirow[t]{2}{*}{ AOR $(95 \% \mathrm{Cl})$} & \multirow[t]{2}{*}{$p$} \\
\hline & & Yes, n (\%) & No, n (\%) & & & & \\
\hline ANC follow-up(s) & $\begin{array}{l}\text { Zero } \\
\text { One } \\
\text { Two } \\
\text { Three } \\
\text { Four and above }\end{array}$ & $\begin{array}{l}1,112(61.7) \\
165(67.3) \\
248(62.8) \\
565(60.6) \\
1,070(53.6)\end{array}$ & $\begin{array}{l}691(38.3) \\
80(32.7) \\
147(37.2) \\
368(39.4) \\
925(46.4)\end{array}$ & $\begin{array}{l}\mathrm{I} .445(\mathrm{I} .26 \mathrm{I}-\mathrm{I} .655) \\
\mathrm{I} .903(\mathrm{I} .408-2.572) \\
\mathrm{I} .398(\mathrm{I} . \mathrm{I} \mathrm{I}-\mathrm{I}-758) \\
\mathrm{I} .227(\mathrm{I} .044-\mathrm{I} .444) \\
\mathrm{I}\end{array}$ & $\begin{array}{l}<0.001 * \\
<0.001^{*} \\
0.004^{*} \\
0.013^{*}\end{array}$ & $\begin{array}{l}\text { I.II5 }(0.923-1.345) \\
\text { I.50। }(1.017-1.216) \\
\text { I.I }(0.862-1.549) \\
\text { I.I52 (0.933-I.422) } \\
\text { I }\end{array}$ & $\begin{array}{l}0.258 \\
0.041^{*} \\
0.333 \\
0.187\end{array}$ \\
\hline Deworming during pregnancy & $\begin{array}{l}\text { Yes } \\
\text { No }\end{array}$ & $\begin{array}{l}|8|(56.2) \\
2,953(58.9)\end{array}$ & $\begin{array}{l}|4|(43.8) \\
2,06 \mid(4|.|)\end{array}$ & $\begin{array}{l}\text { I } \\
\text { I.I } 182(0.936,1.492)\end{array}$ & 0.161 & I & \\
\hline Recent diarrhea & $\begin{array}{l}\text { Yes } \\
\text { No }\end{array}$ & $\begin{array}{l}602(61.9) \\
4,015(55.9)\end{array}$ & $\begin{array}{l}371(38.1) \\
3,167(44.1)\end{array}$ & $\begin{array}{l}1.201(1.042,1.385) \\
।\end{array}$ & $0.011^{*}$ & $\begin{array}{l}0.928(0.756-1.139) \\
\mathrm{I}\end{array}$ & 0.475 \\
\hline Vitamin $A$ in last 6 months & $\begin{array}{l}\text { Yes } \\
\text { No }\end{array}$ & $\begin{array}{l}2,095(54.0) \\
2,450(59.1)\end{array}$ & $\begin{array}{l}\mathrm{I}, 788(46.0) \\
\mathrm{I}, 697(40.9)\end{array}$ & I $1.302(1.187-1.428)$ & $<0.001 *$ & I $1.029(0.886-1.195)$ & 0.705 \\
\hline Level of stunting & $\begin{array}{l}\text { Severe } \\
\text { Moderate } \\
\text { Normal }\end{array}$ & $\begin{array}{l}864(64.9) \\
902(56.6) \\
2,567(53.8)\end{array}$ & $\begin{array}{l}468(35.1) \\
691(43.4) \\
2,205(46.2)\end{array}$ & $\begin{array}{l}\mathrm{I} .609(\mathrm{I} .4 \mid 4-1.830) \\
\mathrm{I} .122(0.999-1.259) \\
\mathrm{I}\end{array}$ & $\begin{array}{l}<0.001 * \\
0.052\end{array}$ & $\begin{array}{l}\text { I. } 467(1.142-1.885) \\
\text { I.I } 178(0.973-1.425) \\
\mathrm{I}\end{array}$ & $\begin{array}{l}0.003^{*} \\
0.092\end{array}$ \\
\hline Level of underweight & $\begin{array}{l}\text { Severe } \\
\text { Moderate } \\
\text { Normal }\end{array}$ & $\begin{array}{l}410(71.1) \\
752(60.4) \\
3,107(53.8)\end{array}$ & $\begin{array}{l}166(28.9) \\
493(39.6) \\
2,669(46.2)\end{array}$ & $\begin{array}{l}2.187(1.819-2.628) \\
1.315(1.166-1.484) \\
1\end{array}$ & $\begin{array}{l}<0.001 * \\
<0.001 *\end{array}$ & $\begin{array}{l}\text { I.458 (I.044-2.035) } \\
\text { I.04I (0.840-I.289) } \\
\text { I }\end{array}$ & $\begin{array}{l}0.027^{*} \\
0.714\end{array}$ \\
\hline Level of wasting & $\begin{array}{l}\text { Severe } \\
\text { Moderate } \\
\text { Normal }\end{array}$ & $\begin{array}{l}\mid 43(73.2) \\
36 \mid(64.4) \\
3,777(55.2)\end{array}$ & $\begin{array}{l}53(26.8) \\
200(35.6) \\
3,065(44.8)\end{array}$ & $\begin{array}{l}2.312(1.698-3.148) \\
I .487(1.254-1.764) \\
I\end{array}$ & $\begin{array}{l}<0.001^{*} \\
<0.001^{*}\end{array}$ & $\begin{array}{l}\text { I.380 (0.8I8-2.326) } \\
\mathrm{I} .088(0.8 \mathrm{I} 3-\mathrm{I} .456) \\
\mathrm{I}\end{array}$ & $\begin{array}{l}0.227 \\
0.570\end{array}$ \\
\hline
\end{tabular}

Note: *Significant association.

Abbreviations: $\mathrm{HH}$, household; ANC, antenatal care.

\section{Limitations}

A limitation of this study was its cross-sectional design, which does not allow the identification of precedence in time between exposure and outcome (chicken-egg dilemma). There were missing values for some variables in the data set. The authors might have failed to consider some important factors that could affect interpretation of the results, and due to the retrospective nature of the data and verbal reports, recall bias might have been introduced.

\section{Conclusion}

Increased child age, decreased maternal age, poorest rank of wealth index, mother living alone, mother engaged in outside work, increased birth order, decreased birth interval, one ANC visit only, severe stunting, and severe underweight were identified as significant predictors of childhood anemia. The prevalence of anemia in this study was the highest from all EDHS reports, which makes it the main public health concern in Ethiopia. Comprehensive intervention strategies should be in place tailored to different levels of government for combating childhood anemia by focusing on the identified risk factors. We advise that health authorities design different nutrition-intervention initiatives like multimineral supplementation (mineral sprinkle), nutrition education, and continuous monitoring of the anemia status of children. In addition, further longitudinal study is needed to rule out the cause-andeffect relationship between childhood anemia and various explanatory variables.

\section{Abbreviations}

ANC, antenatal care; BMI, body-mass index; EDHS, Ethiopia Demographic and Health Survey; HH, household; WHO, World Health Organization.

\section{Data Sharing Statement}

The main part of the data generated or analyzed during this study is included in this article, and if necessary the data are accessible from the corresponding author (AG). 


\section{Author Contributions}

All authors contributed to data analysis, drafting or revising the article, have agreed on the journal to which the article will be submitted, gave final approval to the version to be published, and agree to be accountable for all aspects of the work.

\section{Disclosure}

The authors declare that they have no conflicts of interest for this work.

\section{References}

1. World Health Organization. Micronutrient deficiency: battling iron deficiency anemia: the challenge; 2004. Available from: http://www. who.int/nut/ida.htm. Accessed March 15, 2021.

2. Black RE, Allen LH, Bhutta ZA, et al. Maternal and child undernutrition study group. Maternal and child undernutrition: global and regional exposures and health consequences. Lancet. 2008;371 (9608):243-260. doi:10.1016/S0140-6736(07)61690-0

3. WHO. The global prevalence of anaemia in 2011. Geneva: World Health Organization; 2015. Available from: http://www.who.int/iris/ handle/10665/177094. Accessed March 15, 2021.

4. Chatterjee A, Bosch RJ, Kupka R, et al. Predictors and consequences of anemia among antiretroviral-naïve HIV-infected and HIVuninfected children in Tanzania. Public Health Nutr. 2010;13 (2):289-296.

5. WHO. Hemoglobin concentrations for the diagnosis of anemia and assessment of severity Vitamin and Mineral Nutrition Information System. Geneva: World Health Organization; 2011.

6. Walter T, de Andraca I, Chadud P, et al. Iron deficiency anemia: adverse effects on infant psychomotor development. Pediatrics. 1989;84(1):7-17.

7. McLean E, Cogswell M, Egli I, et al. Worldwide prevalence of anaemia, WHO Vitamin and Mineral Nutrition Information System, 1993-2005. Public Health Nutr. 2009;12(4):444-454. doi:10.1017/ S1368980008002401

8. Allen LH, De Benoist B, Dary O, et al; World Health Organization. Guidelines on food fortification with micronutrients. Geneva: World Health Organization; 2006.

9. Scott SP, Chen-Edinboro LP, Caulfield LE, et al. The impact of anemia on child mortality: an updated review. Nutrients. 2014;6 (12):5915-5932.

10. Moschovis PP, Wiens MO, Arlington L, et al. Individual, maternal and household risk factors for anemia among young children in sub-Saharan Africa: a cross sectional study. BMJ Open. 2018;8: e019654. doi:10.1136/bmjopen-2017-019654

11. Ethiopia Demographic and Health Survey. Addis Ababa: Ethiopian Central Statistical Agency; 2016.

12. Woodruff BA, Wirth JP, Ngnie-Teta I, et al. Determinants of stunting, wasting, and anemia in guinean preschool-age children: an analysis of DHS data from 1999, 2005, and 2012. Food Nutr Bull. 2018;39 (1):39-53.

13. Teshale AB, Tesema GA, Worku MG, et al. Anemia and its associated factors among women of reproductive age in eastern Africa: a multilevel mixed-effects generalized linear model. PLoS One. 2020;15(9):e0238957. doi:10.1371/journal.pone.0238957

14. Ntenda AM, Nkoka O, Bass P. Maternal anemia is a potential risk factor for anemia in children aged 6-59 months in Southern Africa: a multilevel analysis.BMC. Public Health. 2018;18(650). doi:10.11 86/s12889-018-5568-5
15. Tusting LS, Gething PW, Gibson HS, et al. Housing and child health in sub-Saharan Africa: a cross-sectional analysis. PLoS Med. 2020;17 (3):e1003055. doi:10.1371/journal.pmed.1003055

16. WHO Multicentre Growth Reference Study Group. WHO child growth standards: length/height-for-age, weight-forage, weight-forlength, weight-for-height and body mass index-for-age: methods and development. Geneva, Switzerland; 2006.

17. Rutstein SO. The DHS wealth index: approaches for Rural and Urban Areas. DHS working papers. demographic and health research; 2008:60. Available from http://www.dhsprogram.com/pubs/pdf/ WP60/WP60.pdf. Accessed March 15, 2021.

18. Misganaw A, Haregu TN, Deribe K, et al. National mortality burden due to communicable, non-communicable, and other diseases in Ethiopia, 1990-2015: findings from the Global Burden of Disease Study. Popul Health Metr. 2015;15(29). doi:10.1186/s129630170 145-1

19. World Health Organization. Iron deficiency anemia: assessment, prevention, and control. In: (WHO/NHD/01. 3). A Guide for Programme Managers. Geneva: WHO; 2001:1-132.

20. Kuziga F, Adoke Y, Wanyenze R. Prevalence and factors associated with anaemia among children aged 6 to 59 months in Namutumba district, Uganda: a cross- sectional study. BMC Pediatr. 2017;17(25). doi:10.1186/s12887-017-0782-3

21. Khan JR, Awan N, Misu F. Determinants of anemia among 6-59 months aged children in Bangladesh: evidence from nationally representative data. BMC Pediatr. 2016;16:3. doi:10.1186/s12887-0150536-z

22. Melku M, Alene KA, Terefe B, et al. Anemia severity among children aged 6-59 months in Gondar town, Ethiopia: a communitybased cross-sectional study. Ital J Pediatr. 2018;44:107. doi:10. 1186/s13052-018-0547-0

23. Stoltenburg AA, Kemmer TM, Gidvani-Diaz V, et al. Mapping of anemia prevalence in rural honduran children ages 6 to 60 months. J Hum Nutr Food Sci. 2016;4(3):108. doi:10.1096/fasebj.24. 1_supplement.538.9

24. Nambiema A, Robert A, Yaya I. Prevalence and risk factors of anemia in children aged from 6 to 59 months in Togo: analysis from Togo demographic and health survey data, 2013-2014. BMC Public Health. 2019;19(215). doi:10.1186/s12889-019-6547-1

25. Ewusie JE, Ahiadeke C, Beyene J, et al. Prevalence of anemia among under-5 children in the Ghanaian population: estimates from the Ghana demographic and health survey. BMC Public Health. 2014;14:626. doi:10.1186/1471-2458-14-626

26. Gebreweld A, Ali N, Ali R, et al. Prevalence of anemia and its associated factors among children under five years of age attending at Guguftu health center, South Wollo, Northeast Ethiopia. PLoS One. 2019;14(7): 0218961.

27. Gebreegziabiher G, Etana B, Niggusie D. Determinants of Anemia among Children Aged 6-59 Months Living in KilteAwulaeloWoreda, Northern Ethiopia. Anemia. 2014;2014:1-9. doi:10.1155/2014/ 245870

28. Pita GM, Jiménez S, Basabe B, et al. Anemia in children under five years old in Eastern Cuba, 2005-2011. MEDICC Rev. 2014;16 (1):16-23.

29. Disha A, Tharaney M, Abebe Y, et al. Factors associated with Infant and young child feeding practices in Amhara region and nationally in Ethiopia: analysis of the 2005 and 2011 demographic and health surveys. Washington, DC: Alive and Thrive; 2015.

30. Leal LP, Filho MB. Prevalence of anemia and associated factors in children aged 6-59 months in Pernambuco, Northeastern Brazil. Rev Saude Publica. 2011;45(3):457-466. doi:10.1590/s0034-8910201100 0300003

31. Cardoso MA, Scopel KK, Muniz PT, et al. Underlying factors associated with anemia in Amazonian children: a population-based, cross-sectional study. PLoS One. 2012;7(5):e36341. doi:10.1371/ journal.pone. 0036341 
32. Hurtado EK, Claussen AH, Scott KG. Early childhood anemia and mild or moderate mental retardation. Am $J$ Clin Nutr. 1999;69:115-119. doi:10.1093/ajcn/69.1.115

33. Nkulikiyinka R, Binagwaho A, Palmer K. The changing importance of key factors associated with anaemia in 6- to 59-month-old children in a sub-Saharan African setting where malaria is on the decline: analysis of the Rwanda Demographic and Health Survey 2010. Trop Med Int Health. 2015;20(12):1722-1732. doi:10.1111/tmi.12604

34. Engidaye G, Melku M, Yalew A, et al. Under nutrition, maternal anemia and household food insecurity are risk factors of anemia among preschool aged children in Menz Gera Midir district, Eastern Amhara, Ethiopia: a community based cross-sectional study. BMC Public Health. 2019;19:968. doi:10.1186/s12889-019. 7293-0

35. Oliveira M, Martorell R, Nguyen P. Risk factors associated with hemoglobin levels and nutritional status among Brazilian children attending daycare centers in Sao Paulo city, Brazil. Arch Latinoam Nutr. 2010;60(1):23.

36. Assefa S, Mossie A, Hamza L. Prevalence and severity of anemia among school children in Jimma Town, Southwest Ethiopia. BMC Hematol. 2014;14:3. doi:10.1186/2052-1839-14-3

37. Agho KH, Dibley MJ, Este CD, et al. Factors associated with haemoglobin concentration among timor-leste children aged 6-59 months. J Health Popul Nutr. 2008;26(2):200-209.

38. Ray S, Chandra J, Bhattacharjee J, et al. Determinants of nutritional anemia in children less than five years age. Int $J$ Contemp Pediatr. 2016;3(2):403-408. doi:10.18203/2349-3291.ijcp20161023
39. Kotecha PV. Nutritional anemia among young children with focus on Asia and India. Indian J Community Med. 2011;36:8-16.

40. Sinha N, Deshmukh PR, Garg BS. Epidemiological correlates of nutritional anemia among children (6-35 Months) In Rural Wardha, Central India. Indian J Med Sci. 2008;62(2):45-54. doi:10.4103/ 0019-5359.39366

41. Czajka-Narins DM, Haddy TB, Kallen DJ. Nutrition and social correlates in iron deficiency anemia. Am J Clin Nutr. 1978;31:955-960. doi:10.1093/ajcn/31.6.955

42. Afeworki R, Smits J, Tolboom J. Positive Effect of Large Birth Intervals on Early Childhood Hemoglobin Levels in Africa Is Limited to Girls: cross-Sectional DHS Study. PLoS ONE. 2015;10 (6). doi:10.1371/journal.pone.0131897

43. Endris N, Asefa H, Dube L. Prevalence of Malnutrition and Associated Factors among Children in Rural Ethiopia. Biomed Res Int. 2017;2017:1-6. doi:10.1155/2017/6587853

44. Ethiopia Health and Nutrition Research Institute (EPHI). Ethiopia. Determinants of nutritional status of women and children in Ethiopia. AddisAbaba:EPHI; 2004. Available from: https://dhsprogram.com/ pubs/pdf/FA39/02-nutrition.pdf. Accessed December 8, 2019.

45. Woldemariam G, Genebo T. Determinants of nutritional status of women and children in Ethiopia, Calverton, Maryland, USA: ORC Macro; 2002.

46. Jufar AH, Zewde T. Prevalence of anemia among pregnant women attending antenatal care at tikuranbessa specialized hospital, Addis Ababa Ethiopia. J Hematol Thromb Dis. 2014;2:1.

\section{Publish your work in this journal}

Pediatric Health, Medicine and Therapeutics is an international, peerreviewed, open access journal publishing original research, reports, editorials, reviews and commentaries. All aspects of health maintenance, preventative measures and disease treatment interventions are addressed within the journal. Practitioners from all disciplines are invited to submit their work as well as healthcare researchers and patient support groups. The manuscript management system is completely online and includes a very quick and fair peer-review system. Visit http://www.dovepress.com/testimonials.php to read real quotes from published authors. 